\title{
Strategies for smarter catchment hydrology models: incorporating scaling and better process representation
}

Roy C. Sidle $\mathrm{e}^{1,2,3^{*}}$ (D)

\begin{abstract}
Hydrological models have proliferated in the past several decades prompting debates on the virtues and shortcomings of various modelling approaches. Rather than critiquing individual models or modelling approaches, the objective here is to address the critical issues of scaling and hydrological process representation in various types of models with suggestions for improving these attributes in a parsimonious manner that captures and explains their functionality as simply as possible. This discussion focuses mostly on conceptual and physical/process-based models where understanding the internal catchment processes and hydrologic pathways is important. Such hydrological models can be improved by using data from advanced remote sensing (both spatial and temporal) and derivatives, applications of machine learning, flexible structures, and informing models through nested catchment studies in which internal catchment processes are elucidated. Incorporating concepts of hydrological connectivity into flexible model structures is a promising approach for improving flow path representation. Also important is consideration of the scale dependency of hydrological parameters to avoid scale mismatch between measured and modelled parameters. Examples are presented from remote high-elevation regions where water sources and pathways differ from temperate and tropical environments where more attention has been focused. The challenge of incorporating spatially and temporally variable water inputs, hydrologically pathways, climate, and land use into hydrological models requires modellers to collaborate with catchment hydrologists to include important processes at relevant scales-i.e. develop smarter hydrological models.
\end{abstract}

Keywords: Hydrological processes, Remote sensing, Catchment models, Hydrological connectivity, Spatial-temporal scaling, Flexible model structure, Parsimonious models

\section{Introduction}

Hydrological models have evolved with greater complexity due to increased computational power and spatial-temporal data availability from satellites. Precipitation-runoff processes have been simulated at scales ranging from hillslopes to catchments to large river basins to continents with varying degrees of specificity of flow paths that generally decrease at broader scales (e.g.,

\footnotetext{
${ }^{*}$ Correspondence: roy.sidle@ucentralasia.org

${ }^{1}$ Mountain Societies Research Institute, University of Central Asia, Khorog GBAO 736000, Tajikistan

Full list of author information is available at the end of the article
}

Quinn et al. 1991; Refsgaard and Knudsen 1996; Thanapakpawin et al. 2007; Gosling et al. 2011; Abbaspour et al. 2015; Beck et al 2017). Nevertheless, just because models now have more discrete spatial and temporal characterization of catchment attributes (i.e. more complex), does not necessarily equate with an improved representation of hydrological processes, including how water and material transport (e.g., nutrients, pollutants, sediments) processes change with increasing spatial scale (Cammeraat 2002; Lane et al. 2009; Mockler et al. 2016; Sidle et al. 2017). As such, a critical observer may ask whether we are creating more complex hydrological models that focus on accuracy of spatially explicit model outputs for 
the wrong reasons. This begs the need to ensure hydrological models capture reasonably accurate processes at appropriate scales (Blöschl and Sivapalan 1995; Sidle 2006). Furthermore, in many remote and developing regions of the world where data are sparse, huge assumptions are required to parameterize the spatial complexity of drainage basins, thus requiring extensive calibration to produce questionable spatially explicit results (Andersen et al. 2001; Chen et al. 2017). Clearly, for many applications, there is a need to develop 'smarter' hydrological models that are compatible with the available data, characterize processes across multiple scales, capture relevant water sources, are not excessively complex, and, importantly, address the relevant questions at hand.

One of the limitations of most catchment or river basin hydrology models is that they are tested based on runoff responses at their outlets. While this practice may seem reasonable and is certainly appropriate for applications such as downstream flood assessment at a specific site, it does not ensure that internal processes within the catchment are accurately captured (Sidle 2006). As such, it is difficult, if not impossible, to quantitatively assess the effects of spatially distributed land management practices or heterogeneous inputs of precipitation on runoff behaviour. Of course, many distributed models can incorporate complex patterns of land use (e.g., Heuvelmans et al. 2004; Cuo et al. 2008; Tan et al. 2015; Yang et al. 2017); however, if accuracy and robustness of model predictions are only evaluated based on hydrological response at catchment outlets, many combinations of land management effects could produce similar outcomes (Moore and Grayson 1991). This issue of equifinality plagues many contemporary catchment hydrology model applications (Klemeš 1986).

Nonlinear dynamics in hydrological systems poses substantial challenges in catchment models (Beven 1995). Point scale parameters (e.g., saturated hydraulic conductivity, $K_{\mathrm{s}}$ ) or flow descriptors (e.g., Richards equation, Hortonian overland flow contributions) cannot be easily upscaled and thus are often calibrated against the predictor variable (e.g., discharge at the catchment outlet) or within the flow equations. The spatial variability of $K_{\mathrm{s}}$ has been recognized and assessed across landscapes with respect to geomorphology and impacts of land management (e.g., Mohanty and Mousli 2000; Ziegler et al. 2006, 2007; Bevington et al. 2016). Variability in $K_{\mathrm{s}}$ plays an important role in routing subsurface water through hillslopes and catchments and controlling where and to what extent infiltration-excess overland flow propagates during storms (Sidle et al. 2007; Gomi et al. 2008; Miyata et al. 2019). While the dependency of $K_{\mathrm{s}}$ measurements on scale is known (Pachepsky and Hill 2017), it is usually not applied in catchment models. In most (but not all) cases, larger size samples (or domains) for characterizing in situ $K_{\mathrm{s}}$ yield higher and more realistic values for fieldscale applications in heterogeneous media compared to small size (e.g., soil cores) samples (Arya et al. 1998; Nilsson et al. 2001). At hillslope scales, effective $K_{\mathrm{s}}$ appears to be more affected by self-organized behaviour of the soil fabric rather than simple randomness of $K_{\mathrm{s}}$ in the landscape (Blöschl and Sivapalan 1995; Sidle et al. 2000).

Other examples of nonlinear hydrologic responses include timing and spatial organization of preferential flow (Tsuboyama et al. 1994; Sidle et al. 2001), infiltration/runoff domains (Gomi et al. 2008; Miyata et al. 2019), discharge from zero-order basins (hollows) (Sidle et al. 2000; Tsuboyama et al. 2000), rapid subsurface flow generation (Scaife et al. 2020), areas of saturation overland flow (Dunne and Black 1970; Tanaka et al. 1988), exfiltration from fractured bedrock (Montgomery et al. 1997; Kosugi et al. 2006), and baseflow/groundwater storage relationships (Wittenberg 1999). These natural hydrologic nonlinearities are exacerbated by both extensive (e.g., agriculture, forest management, grazing) and intensive (e.g., roads, trails, building sites) management practices. Such anthropogenic activities create complex assemblages of runoff and flow disruptions in surface and subsurface soils, which pose problems for modelling.

This paper represents a further development of the 2017 AOGS Hydrological Sciences Distinguished Lecture delivered by the author and suggests ways of better incorporating process knowledge and scaling information into hydrological models for various applications. Herein, I attempt to articulate some of these process scaling concepts in a domain that formerly focused on statistical scaling (e.g., Gupta and Dawdy 1995; Gupta et al. 1996). Firstly, the strengths and weaknesses of a range of modelling approaches are evaluated and discussed. Next, examples of: (1) using better algorithms and representation of spatially and temporally distributed hydrological processes, including the more efficient use of remotely sensed data; (2) introducing the concept of hydrological connectivity to improve runoff prediction; and (3) employing flexible model structures are presented.

\section{Hydrological modelling approaches}

Hydrological modelling approaches can be divided in three general groups: (1) empirical or statistical models; (2) conceptual models; and (3) physical or processbased models (Refsgaard and Knudsen 1996; Sitterson et al. 2017; Beven 2019). Here and in the sections that follow, the focus is on attributes of models or model advances that may facilitate better opportunities for process representation and hydrological scaling, not simply the ability of models to simulate reasonably accurate downstream hydrographs. In this regard, identifying and 
differentiating amongst the dominant water sources and hydrological processes is essential for selecting the most effective or efficient model, as well as articulating the best conceptual representation of runoff behaviour, regardless of scale. Such considerations and improvements will greatly benefit the utility of models to capture internal catchment processes and advance their use in assessing spatially and temporally distributed land use practices.

Empirical/statistical models are typically 'black box', data driven, and lack connections with physical processes in the catchment. Examples of such models include the Curve Number approach, Artificial Neural Networks, and regression models. There are two types of applications: (1) models developed and trained on rainfallrunoff relationships, such as artificial neural network models (e.g., Srinivasula and Jain 2006); and (2) models developed for ungauged catchments where no discharge data exist, and predictions are made based on empirical parameters transposed from hydrologically similar and proximate gaged catchments (e.g., Blöschl 2005). Advancements have been achieved in both model types to capture some aspects of catchment characteristics (e.g., Blöschl 2005; Young 2006; Asadi et al. 2019), and their relative simplicity in terms of data requirements makes these models attractive in data-sparse regions or in ungagged catchments; however, physical processes operating at different scales within the catchment are not captured. Thus, one of the main errors in these models results from poor representation of spatially and temporally distributed precipitation, although they may accurately predict discharge at the calibrated downstream location (but not within the catchment) (Sitterson et al. 2017). While significant improvements have been made in capturing the nonlinear behaviour of rainfall-runoff processes (e.g., Sivakumar et al. 2001; Mehr and Nourani 2017), given that empirical/statistical models lack fundamental catchment information that affects hydrological response, they are not ideal for prediction proposes in catchments or basins where complex land cover and geomorphic units exist, nor can they capture land use change effects.

Conceptual hydrological models link various hydrological components in the catchment with relatively simple, but functional, algorithms that describe the overall hydrologic processes. Parameters imbedded in these algorithms may not have a direct physical interpretation and must be calibrated to achieve an optimal agreement between outputs of the system and model (Wagener et al. 2001). These models may comprise multiple reservoirs or tanks linked in series to represent exchange of water amongst the atmosphere, surface, and subsurface, including soil and groundwater components. Extensive meteorological and hydrological data are usually required to calibrate and ultimately test the sensitivity of different parameters with respect to hydrological system response (Freer et al. 1996; Wagener et al. 2001). The calibration involves curve fitting, which requires a period of historical data to calibrate the model and complicates inferences related to land use change (Beven and O'Connell 1982; Devi et al. 2015). In heavily parameterized conceptual models, as well as complex process-based models, various approaches to sensitivity analysis may need to be compared prior to hydrological modelling to facilitate the most robust model performance and to screen out unnecessary parameters (Song et al. 2015).

The tank model concept, introduced in Japan (Sugawara 1961), has gained popularity given its lumped representation of runoff processes, description of hydrologic pathways, simple structure, ease of calculations, and often better performance compared to other models (Yokoo et al. 2001; Johnson et al. 2003; Phuong et al. 2018). Such conceptual models generally do not consider detailed catchment characteristics or their spatial variability (Sitterson et al. 2017); however, within the last decade applications have successfully applied linked multi-tank models to distinct geomorphic features and soil water pathways in catchments (Sidle et al. 2011).

The Stanford Watershed Model (Crawford and Linsley 1966) was the parent of many subsequent conceptual hydrological models and modelling platforms, including HSPF, SWMM, and BASINS, which were adopted and further developed by US Environmental Protection Agency to deal with pressing point- and non-point pollution issues from the late 1970s onwards. A more recent semi-distributed conceptual model that has been widely used is TOPMODEL (Beven and Kirkby 1979). In addition to being quasi-physically based, TOPMODEL has a simplified structure with flexible time steps, alleviating some of the concerns raised about fixed time-stepping schemes in many conceptual models (Clark and Kavetski 2010). The widely used Soil and Water Assessment Tool (SWAT) is a hybrid model as it benefits from physical process information within the catchment, but in turn, employs conceptual and empirical algorithms like the curve number approach and the hydrological routing function (Arnold 2012; Nguyen et al. 2018).

True physical or process-based models are mathematical formulations that describe the physical laws that govern hydrological processes within a catchmentconservation of mass, momentum, and energy, in and between the surface and subsurface domains; thus, the solutions are three-dimensional and typically numerical (Kampf and Burges 2007; Fatichi 2016). The ability of these models to link parameters with the physical catchment system is their greatest strength, particularly when precise distributed data are available, physical processes 
of the hydrological system are well understood, and proper consideration is given to scaling (Zehe and Blöschl 2004; Sidle et al. 2017; Sitterson et al. 2017). These models have been criticized because of their complexity and large data demands (e.g., Beven and O'Connell 1982; Grayson et al. 1992), but more fundamental issues with most physically based models include misapplication of model assumptions and algorithms, nonlinearity, and incompatibility of the scale of measurements with their use in models (Grayson et al. 1992; Beven 2001; Zehe and Blöschl 2004; Kampf and Burges 2007), thus implying greater insights into inherent hydrological processes than warranted. Nevertheless, the prospect of obtaining better spatially and temporally explicit predictions together with advances in remotely sensed data acquisition and advanced computational power make these models relevant for many applications, such as land use change and non-stationary climates (Fatichi et al. 2016). Examples of popular physically based hydrological models include DHSVM, MIKE SHE, KINEROS, CATFLOW, VELMA, and HEC-HMS. Given the three-dimensional exchange depicted by many of these models (i.e. air-surface-soil/ aquifer), they can simulate catchment interactions with sediments, nutrients, and chemicals (Sitterson et al. 2017).

The spatial representation of hydrological processes in models is somewhat, but not completely, aligned with the previous three model types. This spatial depiction controls how water inputs are applied and routed as surface and subsurface flow through the catchment as affected by vegetation, surface topography, surface and subsurface soil properties, and geology. The spatial structure of hydrological models can be characterized as lumped, semi-distributed, and fully distributed (Sitterson et al. 2017).

Lumped models do not consider heterogeneity of parameters and the entire catchment is generally treated as a homogenous domain (e.g., Moradkhani and Sorooshian 2008). These models require little data, but 'average' catchment properties, if required, are challenging to estimate and often arbitrary. As such, these models are not appropriate for large topographically complex catchments. Most empirical and some conceptual models fall into this category due to their inherent generalizations.

Semi-distributed hydrological models incorporate some degree of spatial variability in the simulation process. The parameters in semi-distributed models can be lumped by sub-catchments (e.g., Ajami et al. 2004) or by geomorphic properties within catchments (e.g., Sidle et al. 2011). While these models produce spatially explicit results, this does not necessarily result in more accurate outputs as more data are required for spatial calibration and evaluation of model performance. Conceptual and hybrid models like TOPMODEL and SWAT are characteristic of semi-distributed models, although some physically based models can be included in this category (Sitterson et al. 2017).

Fully distributed hydrological models are the most complex and data demanding but offer some unique advantages as well as challenges. Because these models specify hydrological processes at small grid scales, they require spatially discrete input parameters to take advantage of their complex structure. Each cell within the distributed model interacts with neighbouring cells to route water through surface and subsurface elements of the catchment. These models have often been criticized for not properly accounting for nonlinear behaviour of hydrological dynamics, difficulties surrounding a priori estimation of model parameters, scale issues, and equifinality, to name a few (e.g., Beven 2001). Although distributed models contain nonlinear functional relationships at the element scale, these equations do not average simply and may not adequately represent the extremes of the nonlinear system of responses (Beven 2001). Furthermore, if distributed models are parameterized using finescale hydrological properties (e.g., hydraulic conductivity derived from soil core samples, which over-represents matrix flow and underestimates preferential flow), then scaling behaviour may not be accurately represented in model results (e.g., Sidle et al. 2017). Nevertheless, fully distributed models that effectively capture the spatial distribution of physical properties across the catchment can be used to estimate flow in ungauged basins, providing that the relationships between model parameters and spatial properties are considered (Refsgaard 1997). Fully distributed models are generally physically based (e.g., MIKE SHE, DHSVM, VELMA, Wflow) and are frequently used to simulate the effects of land use changes on streamflow regime at various spatial and temporal scales (e.g., Cuo et al. 2008; Im et al. 2009; Golden and Knightes 2011; Gebremicael et al. 2019).

\section{Advances in hydrological scaling and process conceptualization}

Clearly, spatial and temporal scaling issues represent important challenges for hydrological modelling. New conceptualizations and approaches have been developed to assess the hydrologic dynamics in soils, runoff behaviour, streamflow response, and coupling atmospheric energy with water balances at various spatial and temporal scales (e.g., Mengelkamp et al. 1999; Batelaan and De Smedt 2007; Sidle et al. 2017; Miyata et al. 2019). Recent developments in remote sensing and passive microwave sensors facilitate better assessment of changes in land cover, precipitation, surface temperatures, snow water 
equivalent, soil moisture, energy budgets, and demographic shifts, as well as near real-time land surface changes, thus improving our ability to better conceptualize how such changes affect hydrological processes (e.g., Schumann et al. 2009; Quinton et al. 2011; Wang et al. 2012; Mohanty et al. 2017; Singh 2018; Jiang and Wang 2019; Koci et al. 2020). Capturing these dynamics at relevant temporal and spatial scales is critically important to better represent hydrological processes in models, as well as associated transport of sediments, nutrients, and contaminants.

Debate persists on the benefits and importance of understanding and articulating fine-scale processes in hydrological models (e.g., Grayson et al. 1992; Beven 2001; Zehe and Blöschl 2004; Silberstein 2006; Kampf and Burges 2007). The answer to this depends on the question being asked and is not always straightforward. While numerous statistical approaches have been applied to upscale hydrological data and, at the same time, infer process changes at different spatial scales (e.g., Gupta and Dawdy 1995; Gupta et al. 1996), these approaches have focused on discharge at catchment outlets and fail to adequately account for within-catchment processes (Blöschl 2005; Sidle 2006).

Numerous methods and approaches have been proposed to select the most appropriate hydrological model and parameters for specific applications (e.g., Freer et al. 1996; Chen and Chau 2006; Moreda et al. 2006; Clark et al. 2008a; Song et al. 2015). Additionally, progress has been made in examining scaling issues related to model parameterization (Kumar et al. 2013) and assessing model errors (Clark et al. 2008b), but hydrological process representation remains a challenge. Even in the wellestablished, semi-distributed Storm Water Management Model (SWMM), calibrated model parameters were highly uncertain in catchments with large impermeable areas and permeable areas that rapidly recover from wet to dry conditions (Awol et al. 2018). While such examples of using statistical approaches to facilitate efficient and parsimonious parameter selection and error analysis are commendable, a necessary first step is to ensure that hydrological process representation and associated scaling measures are robust; in turn, this will help guide model selection and parameterization.

Recent applications of machine learning (ML) and deep learning (DL) models in catchment hydrology have the potential to improve runoff predictions because they are trained on large and highly variable data sets derived from multiple catchments (Kratzert et al. 2019; Nearing et al. 2021). A fundamental premise is that these models have much more degrees of freedom than conceptual models facilitating the development and transferability of hydrological relationships and improving scaling relationships. Also, such models have been applied in ungauged catchments based on the assumption that sufficient data exist in hydrologically similar catchments to provide more accurate simulations in ungauged catchments than other calibrated catchment models (Kratzeret et al. 2019; Oppel and Schumann 2020). While these approaches attempt to seek "truth" in hydrological modelling, the issue of accurately representing internal hydrological behaviour, and therefore the effects of anthropogenic activities remain elusive.

Moving from statistical to more process-based approaches that can be incorporated into models has proven to be challenging. Drawing on a personal example of subsurface flow at a hillslope scale that invoked a series of hydrometric (Sidle et al. 1995; Tsuboyama et al. 2000; Noguchi et al. 2001), conservative tracer (Tsuboyama et al. 1994), staining (Noguchi et al. 1999), and conceptual (Sidle et al. 2000) studies, we can see how the finescale behaviour of subsurface flow during rainfall events is important to properly characterize catchment runoff, particularly defining the sources of nonlinearity and hydrological thresholds related to storm runoff. Upscaling these processes to the catchment scale was accomplished via a nested set of sub-catchments in which measurements were conducted at scales ranging from the entire catchment to a small portion of a hillslope. The findings revealed that exceeding a hydrological threshold of soil moisture was necessary to activate preferential flow in the soil, which ultimately contributed up to $25 \%$ of the total catchment stormflow during the wettest conditions (Sidle et al. 1995). Furthermore, while individual preferential flow paths were quite short, they self-organized and connected to substantial distances upslope as the catchment became wetter (Tsuboyama et al. 1994; Noguchi et al. 1999; Sidle et al. 2001). These field results were later confirmed by a small-scale modelling study that showed how disconnected macropores were able to expand and become connected as the degree of saturation increased (Nieber and Sidle 2010). Nonlinear behaviour was also observed in zero-order basins (hollows), where hydrologic response was triggered by soil moisture thresholds affected by soil depth (Sidle et al. 2000; Tsuboyama et al. 2000). Articulating these nonlinear responses not only improves our understanding of hillslope hydrology, but also specifies which portions of the catchment are most likely to be 'hydrologically active' under various moisture conditions. The temporal contributions of various hydrological pathways in this small Japanese forest catchment were successfully simulated in a semi-distributed, multi-tank model (Kim et al. 2011) coupled with a kinematic wave model to route water within the riparian area and channel (Sidle et al. 2011). This long-term investigation underlines the importance 
of carefully designed field data collection, experimentation, and conceptualization within a nested catchment structure, followed by informed modelling.

Other types of studies have employed nested catchment designs to effectively examine hydrological processes at different scales. Examples include using stable isotopes within a nested mesoscale catchment (Rodgers et al. 2005), a continental scale nested network to assess cumulative catchment effects (Stein et al. 2014), and using a generalized linearized regression model to estimate scaled catchment runoff coefficients for different rainfall and antecedent moisture conditions (Graeff et al. 2012).

It would be reticent not to acknowledge the advances of tracer studies to the understanding of water residence times, hydrograph separation, flow paths, and evapotranspiration processes; however, little progress has been made in seamlessly linking the findings of these extensive and expensive research investments to hydrological modelling. Use of isotope tracers in hydrology date back at least into the 1940s, but progress in bridging these findings to the solution of practical problems has been slow (Phillips 1995). While tracer techniques can help elucidate temporal and spatial patterns of various water sources and pathways, the application of this approach has mostly been confined to constraining estimates of water storage in catchments (e.g., Tetzlaff et al. 2015). Some the more promising applications of tracer techniques to modelling may come by combining this approach with nested catchment and remote sensing studies (Rodgers et al. 2005; Gomi et al. 2010; Tetzlaff et al. 2015). Nevertheless, care needs to be taken to ensure tracer approaches accurately reflect water sources and flow pathways when variable inputs and potential intercompartmental exchanges occur (Luxmoore and Ferrand, 1993; DeWalle and Swistock 1994; Noguchi et al. 1999; Sidle et al. 2000).

\section{Examples of smarter strategies for hydrological models}

Improving spatial and temporal representation in hydrological models

The availability of hydrological datasets derived from remotely sensed data has increased substantially in the past decade, and there is a growing body of research assessing remotely sensed data for hydrological applications. Variables such as topographic data, precipitation, actual evapotranspiration, soil moisture, water elevation, flood inundation extent, and terrestrial water storage variations can now be measured or predicted at different spatial and temporal scales (Houser et al. 1998; Stephens and Kummerow 2007; Schumann et al. 2009; Albergel et al. 2012; Jarihani et al. 2013, 2015b). For example, near-global coverage Digital Elevation Models (DEMs), such as Shuttle Radar Topography Mission (SRTM) and Advanced Spaceborne Thermal Emission and Reflection Radiometer (ASTER), are extensively used for hydrologic-hydrodynamic modelling in remote areas (Jarihani et al. 2015a; Pham et al. 2018). The Global Multi-resolution Terrain Elevation Data 2010 (GMTED2010) includes digital terrain elevation data from SRTM, Canadian elevation data, Spot 5 Reference3D data, and data from the Ice, Cloud, and land Elevation Satellite (ICESat), providing a high level of detail in global topographic coverage at 30-, 15-, and 7.5-arc-second spatial resolutions (Danielson and Gesch, 2011). Nevertheless, some studies have shown considerable errors for runoff and particularly sediment transport using these global remote sensing data due to gradient smoothing and other modifications; thus, such anomalies need to be considered in the selection of appropriate remote data sets (Sharma and Tiwari 2014; Pakoksung and Takagi 2020).

Capturing multiple water inputs in models that fall outside of the normal precipitation domain (glacier and permafrost melt) is very important in high latitude and high elevation environments (Fig. 1). These areas, particularly in the high mountain ranges of Asia (i.e. Water Towers), are very vulnerable to effects of climate change and climate variability given their dependence on snowmelt and glacial melt supplying much of the runoff to river systems and poor communities (Immerzeel et al. 2010). Nevertheless, the impacts of climate change are not consistent, even within Central Asia, nor are the melt rates from glaciers (Immerzeel and Bierkens 2012; Knoche 2017). Hydrological modelling is essentially the only

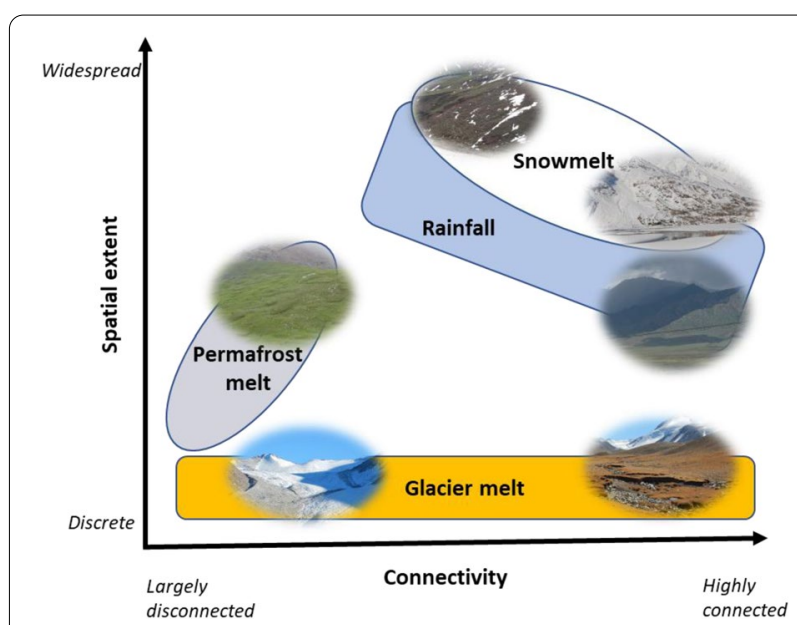

Fig. 1 Example of a conceptual relationship of the spatial extent of dominant water sources and their respective connectivity to channels in high elevation mountains of Central Asia. Such issues need to be considered in hydrological modelling 
way to assess the potential effects of climate change on future changes in discharge regimes, droughts, flooding scenarios, and water-related hazards in these remote but important regions that contribute critical water supplies down river.

Given the paucity of data in these areas, hydrological models must be parsimonious, but able to quantify water sources other than rainfall, such as snowmelt, glacial melt, and even permafrost melt, and appropriately route these through the basin. For example, remotely sensed snow cover data (e.g., Moderate Resolution Imaging Spectroradiometer, MODIS) can be used to produce spatial and temporal patterns of snow cover, which can be modified to remove confounding effects of cloud cover (Gafurov et al. 2016). Relatively simple algorithms need to be developed for snowmelt, glacier melt, and permafrost melt (if relevant) considering the sparse data in these remote high-elevation regions. Glacier evolution can be simulated using a dynamic glacier retreat approach (Huss et al. 2010) and initial glacial conditions and changes can be estimated from surveys or historical remote sensing records. Thus, with rather rudimentary spatially distributed data, hydrological models can be developed to estimate the contributions and timing of various water sources in high altitude mountainous areas (e.g., Duethmann et al. 2014, 2016). Furthermore, the concept of 'hydrological connectivity' (discussed in the next sub-section) can be employed to identify susceptible areas of runoff concentration and link runoff sources to stream channels. In some areas these linkages will be direct and in other cases little runoff will reach channels (Fig. 1).

\section{Incorporating hydrological connectivity into models}

The importance of connectivity of overland flow has be recognized for several decades in terms of water and sediment routing to streams (e.g., Moore and Grayson 1991; Puigdefábregas et al. 1999; Jones et al. 2000; Sidle et al. 2004; Croke et al. 2005). Establishing the connectivity of overland flow from the land surface within the catchment to stream channels requires a conceptualization of hydrologic, land surface, and soil properties. Hydrological connectivity strongly affects the transfer of materials, energy, and even organisms within ecosystems. Examples abound describing how hydrologic connectivity affects both the cumulative and dispersed nature material transport from headwaters to downstream reaches (Gomi et al. 2002); hillslope-riparian-stream transmission of water and chemical constituents (Jencso et al. 2010); species migration, habitat, and refugia (Sedell et al. 1990); integrity of biological reserves at multiple scales (Pringle 2001); potential for groundwater contamination (Sidle et al. 1998); and wetland health (Singh and Sinha 2021), among other ecosystem functionalities.

Building on the early work of Onstad and Brakensiek (1968), Moore et al. (1988) applied digital terrain analysis to develop a contour line-based method (TAPES-C) that subdivides the catchment into irregular polygons bounded by digitized contour lines and adjacent streamlines, thus capturing the effects of complex topography and the connectivity of upslope to downslope elements on flowpaths (Moore and Grayson 1991). While most of the early applications were for surface processes (Hortonian and saturation overland flow), later developments using TAPES-C were used to model the temporal and spatial dynamics of shallow groundwater response in slope stability and sediment routing simulations (Wu and Sidle 1995; Dhakal and Sidle 2004). A later adaptation of this contour-based topographic approach (TOPOTUBE), which included spatial heterogeneity of infiltration capacity based on ground cover, simulated the distributed partitioning of Hortonian overland flow, saturation overland flow, and saturated soil matrix flow, providing reasonable predictions of storm runoff from a small forest catchment (Gomi et al. 2013; Miyata et al. 2019). Nevertheless, the main benefit of such contour-based models appears to be achieving more spatially and temporally explicit representation of internal catchment hydrological and associated material transport processes.

Other studies have focused on how catchment wetness or shallow groundwater depth assessed by indicators such as the topographic index in TOPMODEL (i.e. $\ln (a / \tan \beta)$, where $a$ is the upslope contributing area and $\tan \beta$ is the local slope gradient) inform hydrologic connectivity and nutrient transport across hillslopes and into the riparian zone (e.g., Stieglitz et al. 2003; Detty and McGuire 2010). Later studies have incorporated vegetation patterns and topographic attributes into similar modelling approaches to assess connectivity of both surface and subsurface flow (e.g., Hwang et al. 2012; Hallema et al. 2016).

Several empirical approaches have been developed to assess connectivity of surface runoff within catchments (Bracken and Croke 2007; Borselli et al. 2008; Lane et al. 2009; Reaney et al. 2014). One of the mostly commonly used is the index of runoff and sediment connectivity (IC) developed by Borselli et al. (2008) and later modified and tested for assessing hydrological connectivity at catchment scales (Cavalli et al. 2013; Crema et al. 2015; López-Vicente et al. 2017; Koci et al. 2020). The IC is quantified as a function of average slope gradient, contributing area, and a weighting factor based on the relative 'resistance' of each cell against runoff and sediment flow derived from the $\mathrm{C}$-factor in the Revised Universal Soil Loss Equation (RUSLE) (Borselli et al. 2008). This relatively simple algorithm has been applied in numerous 
studies, but improvements can be made by considering parameters like an index of infiltration capacity, vegetation cover indices, and/or remotely sensed antecedent soil moisture within the weighting factor.

Another approach to quantify hydrologic and associated sediment connectivity is derived from graph theory or its derivative, network theory, in which hydrologic systems are depicted as a collection of nodes that are linked to one another via threshold behaviour (e.g., Halverson and Fleming 2015; Cossart and Fressard 2017). Such network system approaches appear to rely heavily on earlier concepts developed from studies on soil moisture thresholds that control hydrological response and connectivity in catchments (e.g., Sidle et al. 2000; Western et al. 2001). Attempts have also been made to partition water fluxes using stable isotopes to examine the hydrologic connectivity of bound soil water with more mobile surface water (e.g., Good et al. 2015); however, such approaches are based on conservation of flow paths, which are often violated in the complex field systems as previously noted (e.g., Luxmoore and Ferrand 1993), and the findings are difficult to translate into catchment models.

\section{Utilizing flexible model structure}

Typically, trade-offs exist between predicting the timing of the discharge hydrograph and flow volume. Generally, it is very difficult to calibrate both timing and volume of flow in hydrological models. Combined hydrologic-hydrodynamic models can fill this gap by increasing the accuracy of the hydrograph routing while producing acceptable flow volume estimates. For example, TUFLOW employs a rainfall-runoff module for runoff generation and 2-dimensional hydrodynamic equations to route runoff to the catchment outlet. More recent advances in these types of models include the incorporation of a flexible mesh that allows for finer resolution proximate to areas with more complex hydrodynamics (e.g., woody debris in channels, rough channel banks, reaches with high topographic roughness) (Teng et al. 2017). Earlier theoretical research that extended the concept of smoothed particle hydrodynamics (SPH) to deal with free surface incompressible flows (Monaghan 1992) has advanced hydrodynamic modelling as have 3D fluid simulators, which can maximize the relative advantages of using Eulerian and Lagrangian frameworks (Sulsky et al. 1994).

Employing flexible model structure also increases the applicability of models to a broader range of applications. Some modelling approaches provide the user a choice of different processes and modules based on the environment, objectives, and data availability. Moreover, open-source models also provide opportunities for modellers to modify the model structure based on their modelling requirements. For example, the relatively new Wflow model produced by Deltares' (http://www.opens treams.nl) facilitates fully distributed inputs of precipitation, interception, soil water, evapotranspiration, snow accumulation and melt, surface water, and groundwater recharge and uses a kinematic wave routing function. Wflow utilizes open earth observation data and can calculate hydrological fluxes at any geographic location within the model domain for any time step. The structure of the model is transparent and can easily be changed.

To address more complex environmental problems that involve holistic system thinking within the context of environmental decision-making, including socioeconomic activities and policy development, integrated environmental modelling has emerged as a sciencebased structure to organize transdisciplinary knowledge (Laniak 2013). Integrated environmental modelling involves a systems-based approach to environmental modelling that includes multiple models, data bases, and assessment methods that form the basis for constructing a complex simulation system that addresses realworld environmental problems. This system allows for various models to communicate with one another in a 'plug and play' manner whilst embracing the challenge of interoperability, which involves data standardization (Laniak et al. 2013; Whelan 2014a). This approach is far broader in scope than hydrological models per se, but catchment hydrology and related sediment, nutrient, and contaminant transport processes and pathways are typically incorporated-often across the source-to-receptor spectrum (Whelan 2014b). As such, many applications involve water as a primary vector for the fate, transport, and exposure of pollutants.

An example of an integrated modelling application involves the use of the FRAMES (Framework for Risk Analysis in Multi-media Environmental Systems) platform (Gaber et al. 2008) to assess the source, fate, and transport of mercury, as well as the exposure to fish (including bioaccumulation of mercury) within the Albemarle-Pamlico drainage basins in eastern USA (Johnston 2011). FRAMES is linked to Data for Environmental Modeling (D4EM; Wolfe et al. 2014) software that obtains and processes data sets that can be seamlessly used in the integrated modelling exercise. In this application, FRAMES linked five environmental models, including SWAT for catchment runoff, Watershed Mercury Model for mercury runoff and loading to streams, WASP to assess water quality dynamics within the stream system, Habitat Suitability Index model to predict habitat quality for various fish species, and BASS to predict bioaccumulation of mercury and its effect on fish growth and production. Such system-based approaches are very useful, albeit time consuming and complex, to inform 
regulatory policy and decision-making on complex environmental issues.

\section{Prognosis and summary}

Clearly, the selection of the most appropriate hydrological model depends on the problem at hand and the level of complexity needed to satisfactorily address this. Aside from a purely research approach, to be useful for managers, regulators, and other practitioners, the selected hydrological model should be as parsimonious as possible. In some cases, simple empirical, statistical, or conceptual models may be appropriate and sufficient, particularly when only catchment outflow needs to be predicted and where sufficient parameterization data from proximate catchments are available or where "training" data within the designated catchment can be relied on. Herein, the focus is on more complex scenarios where catchment hydrology is affected by spatially and temporally variable water inputs, climate, land use, and demographics where such simple models are of limited relevance. Addressing these more complex effects and interactions may, but does not necessarily, imply a highly sophisticated hydrological model. While the complexity of the hydrological processes and the scaling effects need to be understood, translating these into informative but reasonably simple model algorithms remain the primary challenge. A flow diagram is presented (Fig. 2) that illustrates major data requirements for robust hydrological process representation (blue boxes), broad assessment objectives (white boxes), decision points (green boxes), and key areas for model improvement (yellow boxes) that lead to the selection of the optimal and most parsimonious catchment model (pink boxes). Initially evaluating and understanding the dominant water sources and

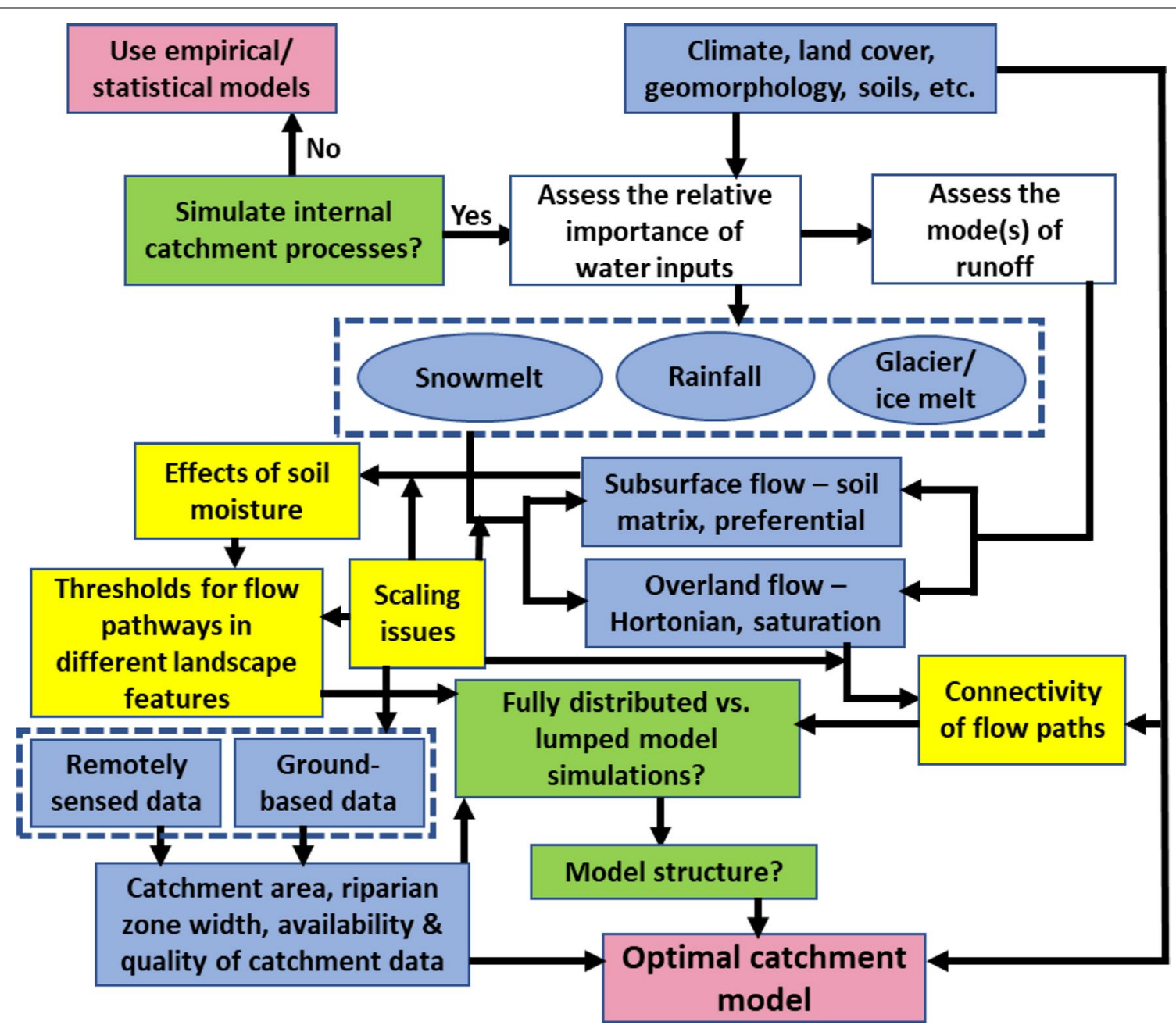

Fig. 2 A framework for illustrating where improvements (yellow boxes) can be achieved in catchment models, as well as requirements for hydrological process representation (blue boxes), broad assessment objectives (white boxes), and major decision points (green boxes) that lead to most optimal and most parsimonious model selection (pink boxes) 
hydrological processes operating at different times within a catchment and then employing a flexible model structure that focuses on the most important hydrological processes is a promising approach that may avoid over parameterization (Fig. 2).

Although many technological advances have been made in the realm of hydrological modelling related to computation, remote data sources, and interoperability, there remain gaps in our ability to effectively incorporate spatial and temporal scaling of hydrological processes into models. This can partly be attributed to the ongoing evolution of concepts in streamflow and stormflow generation, including articulating thresholds for activation of various hydrologic flow paths and geomorphic features in the landscape (Fig. 2). Temporal changes in land cover, climate forcing, water sources, energy budgets, and social dynamics also present challenges for long-term hydrological simulations. Much of these hydrological dynamics have yet to be successfully incorporated into many models despite advances in process understanding. One reason for this gap between process understanding and modelling is that catchment hydrologists have typically not produced robust, scale-dependent algorithms that reflect their level of process understanding; however, another reason is that hydrological modellers continue to embrace algorithms that give reasonably good predictions at catchment outlets without concern for withincatchment processes and pathways-i.e. getting the right answer (at a fixed point) for the wrong reasons.

Advances in remote sensing in the past two decades have the potential to narrow this gap between process hydrologists and modellers. Spatially and temporally variable precipitation, other water inputs, radiation and temperature, soil moisture, and land cover are not only important hydrological controls (Fig. 2), but also affect fluxes of sediments, nutrients, and pollutants from source to sink. The concept of hydrological connectivity, supported by detailed digital elevation models and understanding of subsurface flow dynamics, can be used to better articulate flow pathways using rather simple algorithms (Fig. 2). This can help identify important focal areas for mitigation practices within catchments and thus is a potentially useful tool for managers. These and other innovations that rely on remote sensing and process representation are the best pathways forward for supporting hydrological modelling in remote regions, particularly in poor regions of the world with very limited historical hydrological data, few resources, and little access to ground-based data acquisition systems. Furthermore, to ensure the development of smarter hydrological models, modellers need to work closely with catchment hydrologists to incorporate important processes and scaling concepts.

\section{Acknowledgements}

The ideas in this paper have evolved over several decades and have benefited greatly by discussions with numerous colleagues. Of particular note are earlier discussions with Stephen Burges, Amod Dhakal, Takashi Gomi, Keewook Kim, Gerry Laniak, John Nieber, Tammo Steenhuis, Kate Sullivan, Makoto Tani, Yoshio Tsuboyama, and Daizo Tsutsumi, as well as more recent discussions with Abror Gafurov, Ben Jarihani, and Christian Roth. Much appreciation is extended related to the anonymous reviewer comments and suggestions.

\section{Authors' contributions}

RCS conceptualized and wrote the entire paper based on the Distinguished Lecture in the Hydrological Sciences section of the 2017 AOGS meeting.

Colleagues who have influenced his ideas on this topic during the past years are noted in the Acknowledgements. All authors read and approved the final manuscript.

\section{Funding}

No specific funding supported the production of this paper. The author acknowledges his prior employment at University of the Sunshine Coast, where this paper initiated, along with the continuing support at University of Central Asia.

\section{Availability of data and materials}

In this review paper, any data referred to are available in the sources cited. Please contact the author with any inquiries or questions: roy.sidle@ucentralasia.org.

\section{Declaration}

\section{Competing interests}

The author declares no conflict of interest.

\section{Author details}

${ }^{1}$ Mountain Societies Research Institute, University of Central Asia, Khorog GBAO 736000, Tajikistan. ${ }^{2}$ Sustainability Research Centre, University of the Sunshine Coast, Sippy Downs, QLD 4556, Australia. ${ }^{3}$ Institute of Global Innovation Research, Tokyo University of Agriculture \&Technology, Fuchu, Tokyo 183-8538, Japan.

Received: 30 March 2021 Accepted: 3 June 2021

Published online: 22 June 2021

\section{References}

Abbaspour KC, Rouholahnejad E, Vaghefi S, Srinivasan R, Yang H, Kløve B (2015) A continental-scale hydrology and water quality model for Europe: calibration and uncertainty of a high-resolution large-scale SWAT model. J Hydrol 524:733-752

Ajami NK, Goput H, Wagner T, Sorooshian S (2004) Calibration of a semi-distributed hydrologic model for streamflow estimation along a river system. J Hydrol 298:112-135

Albergel C, De Rosnay P, Gruhier C, Muñoz-Sabater J, Hasenauer S, Isaksen L, Kerr Y, Wagner W (2012) Evaluation of remotely sensed and modelled soil moisture products using global ground-based in situ observations. Remote Sens Environ 118:215-226

Andersen J, Refsgaard JC, Jensen KH (2001) Distributed hydrological modelling of the Senegal River Basin-model construction and validation. J Hydrol 247(3-4):200-214

Arnold JG et al (2012) SWAT: model use, calibration, and validation. Trans Am Soc Agric Biol Eng 55(4):1491-1508

Arya LM, DierolfTS, Sofyan A, Widjaja-Adhi I, van Genuchten MTh (1998) Field measurement of the saturated hydraulic conductivity of a macroporous soil with unstable subsoil structure. Soil Sci 163(11):841-852

Asadi H, Jarihani B, Sidle RC (2019) Rainfall-runoff modelling using hydrological connectivity index and artificial neural network approach. Water 11:212

Awol FS, Coulibaly P, Tolson BA (2018) Event-based model calibration approaches for selecting representative distributed parameters in semiurban watersheds. Adv Water Resour 118:12-27

Batelaan O, De Smedt F (2007) GIS-based recharge estimation by coupling surface-subsurface water balances. J Hydrol 337(3-4):337-355 
Beck HE, van Dijk AIJM, de Roo A, Dutra E, Fink G, Orth R, Schellekens J (2017) Global evaluation of runoff from 10 state-of-the-art hydrological models. Hydrol Earth Syst Sci 21:2881-2903

Beven K (1995) Linking parameters across scales: subgrid parameterizations and scale dependent hydrological models. Hydrol Process 9(5-6):507-525

Beven K (2001) How far can we go in distributed hydrological modelling? Hydrol Earth Syst Sci 5(1):1-12

Beven K (2019) How to make advances in hydrological modelling. Hydrol Res 50(6):1481-1494

Beven KJ, Kirkby MJ (1979) A physically based variable contributing area model of basin hydrology. Hydrol Sci J 24(1):43-69

Beven KJ, O'Connell PE (1982) On the role of physically-based distributed modelling in hydrology. Institute of Hydrology, Report No. 81, Wallingford, UK, p 36

Bevington J, Piragnolo D, Teatini P, Vellidis G, Morari F (2016) On the spatial variability of soil hydraulic properties in a Holocene coastal farmland. Geoderma 262:294-305

Blöschl G (2005) Rainfall-runoff modeling of ungaged catchments. In: Anderson MG (ed) Encyclopedia of hydrological sciences, Chapter 133, John Wiley \& Sons

Blöschl G, Sivapalan M (1995) Scale issues in hydrological modelling: a review. Hydrol Process 9(3-4):251-290

Borselli L, Cassi P, Torri D (2008) Prolegomena to sediment and flow connectivity in the landscape: a GIS and field numerical assessment. CATENA 75(3):268-277

Bracken LJ, Croke J (2007) The concept of hydrological connectivity and its contribution to understanding runoff-dominated geomorphic systems. Hydrol Process 21(13):1749-1763

Cammeraat LH (2002) A review of two strongly contrasting geomorphical systems within the context of scale. Earth Surf Proc Land 27:1201-1222

Cavalli M, Trevisani S, Comiti F, Marchi L (2013) Geomorphometric assessment of spatial sediment connectivity in small Alpine catchments. Geomorphology 188:31-41

Chen W, Chau KW (2006) Intelligent manipulation and calibration of parameters for hydrological models. Int J Environ Pollut 28:432-447

Chen Y, Li W, Fang G, Li Z (2017) Review article: Hydrological modeling in glacierized catchments of central Asia - status and challenges. Hydrol Earth Syst Sci 21:669-684

Clark MP, Kavetski D (2010) Ancient numerical daemons of conceptual hydrological modeling: 1. Fidelity and efficiency of time stepping schemes. Water Resour Res 46:W10510

Clark MP, Slater AG, Rupp DE, Woods RA, Vrugt JA, Gupta HV, Wagener T, Hay LE (2008a) Framework for Understanding Structural Errors (FUSE): a modular framework to diagnose differences between hydrological models. Water Resour Res 44:W00B02

Clark MP, Rupp DE, Woods RA, Zheng X, Ibbitt RP, Slater AG, Schmidt J, Uddstrom MJ (2008b) Hydrological data assimilation with the ensemble Kalman filter: Use of streamflow observations to update states in a distributed hydrological model. Adv Water Resour 31:1309-1324

Cossart E, Fressard M (2017) Assessment of structural sediment connectivity within catchments: insights from graph theory. Earth Surf Dyn $5: 253-268$

Crawford NH, Linsley RK (1966) Digital simulation in hydrology: Stanford Watershed Model IV. Technical Report No. 39, Department of Civil Engineering, Stanford University, p 210

Crema S, Schenato L, Goldin B, Marchi L, Cavalli M (2015) Toward the development of a stand-alone application for the assessment of sediment connectivity. Rendiconti Online Società Geologica Italiana 34:58-61

Croke J, Mockler S, Fogarty P, Takken I (2005) Sediment concentration changes in runoff pathways from a forest road network and the resultant spatial pattern of catchment connectivity. Geomorphology 68:257-268

Cuo L, Lettenmaier DP, Mattheussen BV, Storck P, Wiley M (2008) Hydrologic prediction for urban watersheds with the Distributed Hydrology-SoilVegetation Model. Hydrol Process 22(21):4205-4213

Danielson JJ, Gesch DB (2011) Global multi-resolution terrain elevation data 2010 (GMTED2010). US Department of the Interior, US Geological Survey, open file rep. 2011-1073

Detty JM, McGuire KJ (2010) Topographic controls on shallow groundwater dynamics: implications of hydrologic connectivity between hillslopes and riparian zones in a till mantled catchment. Hydrol Process 24:2222-2236

Devi GK, Ganasri BP, Dwarakish GS (2015) A review on hydrological models. Aquatic Procedia 4:1001-1007

DeWalle DR, Swistock BR (1994) Differences in oxygen-18 content of throughfall and rainfall in hardwood and coniferous forests. Hydrol Process 8:75-82

Dhakal AS, Sidle RC (2004) Pore water pressure assessment in a forest watershed: simulations and distributed field measurements related to forest practices. Water Resour Res 40:W02405

Duethmann D, Menz B, Jiang T, Vorogushyn S (2016) Projections for headwater catchments of the Tarim River reveal glacial retreat and decreasing surface water availability but uncertainties are large. Environ Res Lett 11:054024

Duethmann D, Peters J, Blume T, Vorogushyn S, Güntner A (2014) The value of satellite-derived snow cover images for calibrating a hydrological model in snow-dominated catchments in Central Asia. Water Resour Res 50(3):2002-2021

Dunne T, Black RD (1970) Partial area contributions to storm runoff in a small New England watershed. Water Resour Res 6:1269-1311

Fatichi S et al (2016) An overview of current applications, challenges, and future trends in distributed process-based models in hydrology. J Hydrol 537:45-60

Freer J, Beven KJ, Ambroise B (1996) Bayesian estimation of uncertainty in runoff prediction and the value of data: an application of the GLUE approach. Water Resour Res 32:2161-2173

Gaber N, Laniak G, Linker L (2008) Integrated modeling for integrated environmental decision making. US Environmental Protection Agency White Paper, EPA 100/R-08/010

Gafurov A, Lüdtke S, Unger-Shayesteh K, Vorogushyn S, Schöne T, Schmidt S, Kalashnikova O, Merz B (2016) MODSNOW-Tool: an operational tool for daily snow cover monitoring using MODIS data. Environ Earth Sci 75:1078

Gebremicael TG, Mohamed YA, Van der Zaag P (2019) Attributing the hydrological impact of different land use types and their long-term dynamics through combining parsimonious hydrological modelling, alteration analysis and PLSR analysis. Sci Total Environ 660:1155-1167

Golden HE, Knightes CD (2011) Simulated watershed mercury and nitrate flux responses to multiple land cover conversion scenarios. Environ Toxicol Chem 30(4):773-786

Gomi T, Sidle RC, Richardson JS (2002) Understanding processes and downstream linkages of headwater systems. Bioscience 52(10):905-916

Gomi T, Sidle RC, Miyata S, Kosugi K, Onda Y (2008) Dynamic runoff connectivity of overland flow on steep forested hillslopes: scale effects and runoff transfer. Water Resour Res. https://doi.org/10.1029/2007WR005894

Gomi T, Asano Y, Uchida T, Onda Y, Sidle RC, Miyata S, Kosugi K, Mizugaki S, Fukuyama T, Fukushima T (2010) Evaluation of storm runoff pathways in steep nested Japanese cyprus catchments in central Japan: a geochemical approach. Hydrol Process 24:550-566

Gomi T, Miyata S, Sidle RC, Kosugi K, Onda Y, Hiraoka M, Furuichi T (2013) Analysis of overland flow generation and catchment storm runoff using a distributed runoff model in a headwater catchment draining Japanese cypress forest. J Jpn Forestry Soc 95:23-31 (in Japanese with English abstract)

Good SP, Noone D, Bowen G (2015) Hydrologic connectivity constrains partitioning of global terrestrial fluxes. Science 349:175-177

Gosling S, Taylor R, Arnell N, Todd M (2011) A comparative analysis of projected impacts of climate change on river runoff from global and catchmentscale hydrological models. Hydrol Earth Syst Sci 15(1):279-294

GraeffT, Zehe E, Blume T, Frnacke T, Schröder B (2012) Predicting event response in a nested catchment with generalized linear models and a distributed watershed model. Hydrol Process 26:3749-3769

Grayson RB, Moore ID, McMahon TA (1992) Physically based hydrologic modeling: 2. Is the concept realistic? Water Resour Resour 28(10):2659-2666

Gupta VK, Dawdy DR (1995) Physicals interpretations of regional variations in the scaling exponents of flood quantiles. Hydrol Process 9:347-361

Gupta VK, Castro SL, Over TM (1996) On scaling exponents of spatial peak flows from rainfall and river network geometry. J Hydrol 187(1-2):81-104 
Hallema DW, Moussa R, Sun G, McNulty SG (2016) Surface strom flow prediction on hillslopes based on topography and hydrologic connectivity. Ecol Process 5:13

Halverson MJ, Fleming SW (2015) Complex network theory, streamflow, and hydrometric monitoring system design. Hydrol Earth Syst Sci 19:3301-3318

Heuvelmans G, Muys B, Feyen J (2004) Evaluation of hydrological model parameter transferability for simulating the impact of land use on catchment hydrology. Phys Chem Earth 29:739-747

Houser PR, Shuttleworth WJ, Famiglietti JS, Gupta HV, Syed KH, Goodrich DC (1998) Integration of soil moisture remote sensing and hydrologic modeling using data assimilation. Water Resour Res 34(12):3405-3420

Huss M, Jouvet G, Farinotti D, Bauder A (2010) Future high-mountain hydrology: a new parameterization of glacier retreat. Hydrol Earth Syst Sci 14:815-826

Hwang T, Band LE, Vose JM, Tague C (2012) Ecosystem processes at the watershed scale: Hydrologic vegetation gradient as an indicator for lateral hydrologic connectivity of headwater catchments. Water Resour Res 48:W06514

Immerzeel WW, Bierkens MFP (2012) Asia's water balance. Nat Geosci 5:841-842

Immerzeel WW, van Beek LPH, Bierkens MFP (2010) Climate change will affect the Asian water towers. Science 328:1382-1385

Im S, Kim H, Jang C (2009) Assessing the impacts of land use changes on watershed hydrology using MIKE SHE. Environ Geol 57:231

Jarihani AA, Callow JN, Johansen K, Gouweleeuw B (2013) Evaluation of multiple satellite altimetry data for studying inland water bodies and river floods. J Hydrol 505:78-90

Jarihani AA, Callow JN, McVicar TR, Van Niel TG, Larsen JR (2015a) Satellitederived Digital Elevation Model (DEM) selection, preparation and correction for hydrodynamic modelling in large, low-gradient and data-sparse catchments. J Hydrol 524:489-506

Jarihani AA, Larsen JR, Callow JN, McVicar TR, Johansen K (2015b) Where does all the water go? Partitioning water transmission losses in a data-sparse, multi-channel and low-gradient dryland river system using modelling and remote sensing. J Hydrol 529:1511-1529

Jencso KG, McGlynn BL, Gooseff MN, Bencala KE, Wondzell SM (2010) Hillslope hydrological connectivity controls riparian groundwater turnover: Implications of catchment structure for riparian buffering and stream water sources. Water Resour Res 46:W10524

Jiang D, Wang K (2019) The role of satellite-based remote sensing in improving simulated streamflow: a review. Water 11:1615

Johnson MS, Coon WF, Mehta VK, Steenhuis TS, Brooks ES, Boll J (2003) Application of two hydrologic models with different runoff mechanisms to a hillslope dominated watershed in the northeastern US: a comparison of HSPF and SMR. J Hydrol 284(1-4):57-76

Johnston JM et al (2011) An integrated modeling framework for performing environmental assessments: application to ecosystems services in the Albemarle-Pamlico basins (NC and VA, USA). Ecol Model 222:2471-2484

Jones JA, Swanson FJ, Wemple BC, Snyder KU (2000) Effects of roads on hydrology, geomorphology, and disturbance patches in stream networks. Conserv Biol 14:76-85

Kampf SK, Burges SJ (2007) A framework for classifying and comparing distributed hillslope and catchment hydrologic models. Water Resour Res 43:W05423. https://doi.org/10.1029/2006WR005370

Kim K, Sidle RC, Tsuboyama Y (2011) Modeling storm-runoff dynamics from zero-order basins: implications for hydrological pathways. Hydrol Res Lett 5:6-10

Klemeš V (1986) Dilettantism in hydrology: transition or destiny? Water Resour Res 22(9S):177S-188S

Knoche M et al (2017) Bridging glaciological and hydrological trends in the Pamir Mountains, Central Asia. Water 9:422

Koci J, Sidle RC, Jarihani B, Cashman MJ (2020) Linking hydrological connectivity to gully erosion in savanna rangelands tributary to the Great Barrier Reef using Structure-from-Motion photogrammetry. Land Degrad Dev 31:20-36

Kosugi K, Katsura S, Katsuyama M, Mizuyama T (2006) Water flow processes in weathered granitic bedrock and their effects on runoff generation in a small headwater catchment. Water Resour Res 42(2):W02414
Kratzert F, Klotz D, Herrnegger M, Sampson AK, Hochreiter S, Nearing G (2019) Toward improved predictions in ungauged basins: Exploiting the power of machine learning. Water Resour Res 55:11344-11354

Kumar R, Samaniego L, Attinger S (2013) Implications of distributed hydrologic model parameterization on water fluxes at multiple scales and locations. Water Resour Res. https://doi.org/10.1029/2012WR012195

Lane SN, Reaney SM, Heathwaite AL (2009) Representation of landscape hydrological connectivity using a topographically driven surface flow index. Water Resour Res 45:W08423(8)

Laniak GF et al (2013) Integrated environmental modeling: a vision and roadmap for the future. Environ Model Softw 39:3-23

López-Vicente M, Sun X, Onda Y, Kato H, Gomi T, Hiraoka M (2017) Effect of tree thinning and skidding trails on hydrological connectivity in two Japanese forest catchments. Geomorphology 292:104-114

Luxmoore RJ, Ferrand LA (1993) Towards a pore-scale analysis of preferential flow and chemical transport. In: Russo D, Dagan G (eds) Water flow and solute transport in soils. Springer-Verlag, Berlin, pp 45-60

Mehr AD, Nourni V (2017) A Pareto-optimal moving average-multigene genetic programming model for rainfall-runoff modelling. Environ Model Softw 92:239-251

Mengelkamp H-T, Warrach K, Raschke E (1999) SEWAB — a parameterization of the Surface Energy and Water Balance for atmospheric and hydrologic models. Adv Water Resour 23:165-175

Miyata S, Gomi T, Sidle RC, Hiraoka M, Onda Y, Yamamoto K, Nonoda T (2019) Assessing spatially distributed infiltration capacity to evaluate storm runoff in forested catchments: implications for hydrological connectivity. Sci Total Environ 699:148-159

Mockler EM, O'Loughlin FE, Bruen M (2016) Understanding hydrological flow paths in conceptual catchment models using uncertainty and sensitivity analysis. Comput Geosci 90:66-77

Mohanty BP, Mousli Z (2000) Saturated hydraulic conductivity and soil water retention properties across a soil-slope transition. Water Resour Res 36(11):3311-3324

Mohanty BP, Cosh MH, Lakshmi V, Montza C (2017) Soil moisture remote sensing: state-of-the-science. Vadose Zone Journal 16(1):1-9

Monaghan JJ (1992) Simulating free surface flows with SPH. J Comput Phys 110:399-406

Montgomery DR, Dietrich WE, Torres R, Anderson SP, Heffner JT, Loague K (1997) Hydrologic response of a steep, unchanneled valley to natural and applied rainfall. Water Resour Res 33(1):91-109

Moore ID, Grayson RB (1991) Terrain based prediction of runoff with vector elevation data. Water Resour Res 27:1177-1191

Moore ID, O'Loughlin EM, Burch GJ (1988) A contour-based topographic model for hydrological and ecological applications. Earth Surf Proc Land 13:305-320

Moradkhani H, Sorooshian S (2008) General review of rainfall-runoff modeling: model calibration, data assimilation, and uncertainty analysis. In: Sorooshian S et al (eds) Hydrological modeling in the water cycle: coupling atmospheric and hydrological models. Springer, Berlin, pp 1-24

Moreda F, Koren V, Zhang Z, Reed S, Smith M (2006) Parameterization of distributed hydrological models: learning from the experiences of lumped modeling. J Hydrol 320:218-237

Nearing GS, Kratzert F, Sampson AK, Pelissier CS, Klotz D, Frame JM, Prieto C, Gupta HV (2021) What role does hydrological science play in the age of machine learning? Water Resour Res 57:e2020WR028091

Nguyen VT, Dietrich J, Uniyal B, Tran DA (2018) Verification and correction of the hydrologic routing in the Soil and Water Assessment Tool. Water 10:1419

Nieber JL, Sidle RC (2010) How do disconnected macropores in sloping soils facilitate preferential flow? Hydrol Process 24:1582-1594

Nilsson B, Sidle RC, Klint K, Bøggild C, Broholm K (2001) Mass transport and scale-dependent hydraulic tests in a heterogeneous glacial till-sandy aquifer system. J Hydrol 23(3):162-179

Noguchi S, Tsuboyama Y, Sidle RC, Hosoda I (1999) Morphological characteristics of macropores and distribution of preferential flow pathways in a forested slope segment. Soil Sci Soc Am J 63:1413-1423

Noguchi S, Tsuboyama Y, Sidle RC, Hosoda I (2001) Subsurface runoff characteristics from a forest hillslope soil profile including macropores, Hitachi Ohta, Japan. Hydrol Process 15:2131-2149

Onstad CA, Brakensiek DL (1968) Watershed simulation by the stream path analogy. Water Resour Res 4:965-971 
Oppel H, Schumann AH (2020) Machine learning based identification of dominant controls on runoff dynamics. Hydrol Process 34:2450-2465 Pachepsky Y, Hill RL (2017) Scale and scaling in soils. Geoderma 287:4-30

Pakoksung K, Takagi M (2020) Effect of DEM sources on distributed hydrological model to results of runoff and inundation area. Model Earth Syst Environ. https://doi.org/10.1007/s40808-020-00914-7

Pham HT, Marshall L, Johnson F, Sharma A (2018) A method for combining SRTM DEM and ASTER GDEM2 to improve topography estimation in regions without reference data. Remote Sens Environ 210:229-241

Philips FM (1995) The use of isotopes and environmental tracers in subsurface hydrology. Rev Geophys 33(S2):1029-1033

Phuong HT, Tien NX, Chikamori H, Okubo K (2018) A hydrological tank model assessing historical runoff variation in the Hieu River basin. Asian J Water Environ Pollut 15(1):75-86

Pringle CM (2001) Hydrological connectivity and the management of biological reserves: a global perspective. Ecol Appl 11(4):981-998

Puigdefábregas J, Sole A, Gutierrez L, Del Barrio G, Boer M (1999) Scales and processes of water and sediment redistribution in drylands: results from the Rambla Honda field site in Southeast Spain. Earth Sci Rev 48(1):39-70

Quinn P, Beven K, Chevallier P, Planchon O (1991) The prediction of hillslope flow paths for distributed hydrological modelling using digital terrain models. Hydrol Process 5(1):59-79

Quinton WL, Hayashi M, Chasmer LE (2011) Permafrost-thaw-induced land-cover change in the Canadian subarctic: implications for water resources. Hydrol Process 25:152-158

Reaney SM, Bracken LJ, Kirkby MJ (2014) The importance of surface controls on overland flow connectivity in semi-arid environments: results from a numerical experimental approach. Hydrol Process 28(4):2116-2128

Refsgaard JC (1997) Parameterisation, calibration and validation of distributed hydrological models. J Hydrol 198(1-4):69-97

Refsgaard JC, Knudsen J (1996) Operational validation and intercomparison of different types of hydrological models. Water Resour Res 32(7):2189-2202

Rodgers P, Soulsby C, Waldron S, Tetzlaff D (2005) Using stable isotope tracers to assess hydrological flow paths, residence times and landscape influences in a nested mesoscale catchment. Hydrol Earth Syst Sci 9:139-155

Scaife Cl, Singh NK, Emanuel RE, Miniat CF, Band LE (2020) Non-linear quickflow response as indicators of runoff generation mechanisms. Hydrol Process 34(13):2949-2964

Schumann G, Bates PD, Horritt MS, Matgen P, Pappenberger F (2009) Progress in integration of remote sensing-derived flood extent and stage data and hydraulic models. Rev Geophys 47:RG4001

Sedell JR, Reeves GH, Hauer FR, Stanford JA, Hawkins CP (1990) Role of refugia in recovery from disturbances: modern fragmented and disconnected river systems. Environ Manage 14:711-724

Sharma A, Tiwari KN (2014) A comparative appraisal of hydrological behavior of SRTM DEM at catchment level. J Hydrol 519:1394-1404

Sidle RC (2006) Field observations and process understanding in hydrology: essential components in scaling. Hydrol Process 20:1439-1445

Sidle RC, Nilsson B, Hansen M, Fredericia J (1998) Spatially varying hydraulic and solute transport characteristics of fractured till determined by field tracer tests, Funen, Denmark. Water Resour Res 34(10):2515-2527

Sidle RC, Tsuboyama Y, Noguchi S, Hosoda I, Fujieda M, Shimizu T (1995) Seasonal hydrologic response at various spatial scales in a small forested catchment, Hitachi Ohta, Japan. J Hydrol 168:227-250

Sidle RC, Tsuboyama Y, Noguchi S, Hosoda I, Fujieda M, Shimizu T (2000) Stormflow generation in steep forested headwaters: a linked hydrogeomorphic paradigm. Hydrol Process 14(3):369-385

Sidle RC, Noguchi S, Tsuboyama Y, Laursen K (2001) A conceptual model of preferential flow systems in forested hillslopes: evidence of self-organization. Hydrol Process 15(10):1675-1692

Sidle RC, Sasaki S, Otsuki M, Noguchi S, Abdul RN (2004) Sediment pathways in a tropical forest: effects of logging roads and skid trails. Hydrol Process 18:703-720

Sidle RC, Hirano T, Gomi T, Terajima T (2007) Hortonian overland flow from Japanese forest plantations - an aberration, the real thing, or something in between? Hydrol Process 21(23):3237-3247
Sidle RC, Kim K, Tsuboyama Y, Hosoda I (2011) Development and application of a simple hydrogeomorphic model for headwater catchments. Water Resour Res 47:WOOH13

Sidle RC, Gomi T, Loaiza Usuga JC, Jarihani B (2017) Hydrogeomorphic processes and scaling issues in the continuum from soil pedons to catchments. Earth Sci Rev 175:75-96

Silberstein RP (2006) Hydrological models are so good, do we still need data? Environ Model Softw 21:1340-1352

Singh VP (2018) Hydrologic modeling: progress and future directions. Geosci Lett 5:15

Singh M, Sinha R (2021) Hydrogeomorphic indicators of wetland health inferred from multi-temporal remote sensing for a new Ramsar site (Kaabar Tal), India. Ecol Indicators 17:107739

Sitterson J, Knightes C, Parmar R, Wolfe K, Muche M, Avant B (2017) An overview of rainfall-runoff model types. US Environmental Protection Agency Report EPA/600/R-153, p 29

Sivakumar B, Berndtsson R, Olsson J, Ninno K (2001) Evidence of chaos in the rainfall-runoff process. Hydrol Sci J 46(1):131-145

Song X, Zhang J, Zhan C, Xuan Y, Ye M, Xu C (2015) Global sensitivity analysis in hydrological modeling: review of concepts, methods, theoretical framework, and applications. J Hydrol 523:739-757

Srinivasula S, Jain A (2006) A comparative analysis of training methods for artificial neural network rainfall-runoff models. Appl Soft Comput 6(3):295-306

Stein JL, Hutchinson MF, Stein JA (2014) A new stream and nested catchment framework for Australia. Hydrol Earth Syst Sci 18:1917-1933

Stephens GL, Kummerow CD (2007) The remote sensing of clouds and precipitation from space: a review. J Atmos Sci 64(11):3742-3765

Stieglitz M, Shaman J, McNamara J, Engel V, Shanley J, Kling GW (2003) An approach to understanding hydrologic connectivity on the hillslope and the implications for nutrient transport. Global Biogechemical Cycles 17(4):1105

Sugawara M (1961) On the analysis of runoff structure about several Japanese rivers. Jpn J Geophys 5(2):1-76

Sulsky D, Chen Z, Schreyer HL (1994) A particle method for history-dependent materials. Comput Methods Appl Mech Eng 118:179-196

Tanaka T, Yasuhara M, Sakai H, Marui A (1988) The Hachioji experimental basin study - storm runoff processes and the mechanism of its generation. J Hydrol 102(1):139-164

Tan ML, Ibrahim AL, Yusop Z, Duan Z, Ling L (2015) Impacts of land-use and climate variability on hydrological components in the Johor River basin, Malaysia. Hydrol Sci J 60(5):873-889

Teng J, Jakeman AJ, Vaze J, Croke BFW, Dutta D, Kim S (2017) Flood inundation modelling: A review of methods, recent advances and uncertainty analysis. Environ Model Softw 90:201-216

Tetzlaff D, Buttle J, Carey SK, McGuire K, Laudon H, Soulsby C (2015) Tracerbased assessment of flow paths, storage and runoff generation in northern catchments: a review. Hydrol Process 29:3475-3490

Thanapakpawin P, Richey J, Thomas D, Rodda S, Campbell B, Logsdon M (2007) Effects of landuse change on the hydrologic regime of the Mae Chaem river basin, NW Thailand. J Hydrol 334(1):215-230

Tsuboyama Y, Sidle RC, Noguchi S, Hosoda I (1994) Flow and solute transport through the soil matrix and macropores of a hillslope segment. Water Resour Res 30(4):879-890

Tsuboyama Y, Sidle RC, Noguchi S, Murakami S, Shimizu T (2000) A zero-order basin-its contribution to catchment hydrology and internal hydrological processes. Hydrol Process 14(3):387-401

Wagener T, Boyle DP, Lees MJ, Wheater HS, Gupta HV, Sorooshain S (2001) A framework for development and application of hydrological models. Hydrol Earth Syst Sci 5:13-26

Wang L, D'Odorico P, Evans JP, Eldridge DJ, McCabe MF, Caylor KK, King EG (2012) Dryland ecohydrology and climate change: critical issues and technical advances. Hydrol Earth Syst Sci 16:2585-2603

Western AW, Blöschl G, Grayson RB (2001) Toward capturing hydrologically significant connectivity in spatial patterns. Water Resour Res 37:83-97

Whelan G et al (2014a) Design of a component-based integrated environmental modeling framework. Environ Model Softw 55:1-24

Whelan $\mathrm{G}$ et al (2014b) An integrated environmental modeling framework for performing Quantitative Microbial Risk Assessments. Environ Model Softw 55:77-91 
Wittenberg H (1999) Baseflow recession and recharge as nonlinear storage processes. Hydrol Process 13(5):715-726

Wolfe KL, et al (2014) Data for environmental modeling (D4EM): Background and example applications of data automation. In: Environmental Software Systems (2nd ed.) vol. 7, pp 396-405

Wu W, Sidle RC (1995) A distributed slope stability model for steep forested hillslopes. Water Resour Res 31:2097-2110

Yang L, Feng Q, Yin Z, Wen X, Si J, Li C, Deo RC (2017) Identifying separate impacts of climate and land use/cover change on hydrological processes in upper stream of Heihe River, Northwest China. Hydrol Proces 31(5):1100-1112

Yokoo Y, Kazuma S, Sawamoto M, Nishimura H (2001) Regionalization of lumped water balance based on multiple regression. J Hydrol 246:209-222

Young AR (2006) Stream flow simulation within ungaged UK catchments using a daily rainfall-runoff model. J Hydrol 320(1-2):155-172
Zehe E, Blöschl G (2004) Predictability of hydrologic response at the plot and catchment scales: role of initial conditions. Water Resour Res 40:W10202

Ziegler AD, Negishi JN, Sidle RC, Noguchi S, Abdul RN (2006) Impacts of logging disturbance on hillslope saturated hydraulic conductivity in a tropical forest in Peninsular Malaysia. CATENA 67:89-104

Ziegler AD, Negishi JN, Sidle RC, Gomi T, Noguchi S, Abdul RN (2007) Persistence of road runoff in a logged catchment in Peninsular Malaysia. Earth Surf Proc Land 32:1947-1970

\section{Publisher's Note}

Springer Nature remains neutral with regard to jurisdictional claims in published maps and institutional affiliations.

\section{Submit your manuscript to a SpringerOpen ${ }^{\circ}$ journal and benefit from:}

- Convenient online submission

- Rigorous peer review

- Open access: articles freely available online

- High visibility within the field

- Retaining the copyright to your article

Submit your next manuscript at $\boldsymbol{\nabla}$ springeropen.com 